\title{
Laboratory evaluation of entomopathogenic fungi as biological control agents against the bark beetle Pityogenes scitus Blandford (Coleoptera: Curculionidae) in Kashmir
}

\author{
Abdul L. Khanday ${ }^{1} \bowtie$, Abdul A. Buhroo ${ }^{1}$, Avunjikkattu P. Ranjith ${ }^{2}$,Stawomir Mazur ${ }^{3}$ \\ ${ }^{1}$ University of Kashmir, Post Graduate Department of Zoology, Section of Entomology, Srinagar-190006, \\ Jammu and Kashmir, India, e-mail: lateefkhanday@gmail.com \\ ${ }^{2}$ University of Calicut, Department of Zoology, Insect Ecology and Ethology Laboratory, Kerala-673635, India \\ ${ }^{3}$ University of Łódź Branch in Tomaszów Mazowiecki, Institute of Forest Sciences, Konstytucji 3 Maja 65/67, \\ 97-200 Tomaszów Mazowiecki, Poland
}

\section{Abstract}

The bark beetles (Coleoptera: Curculionidae) are widely recognised as one of the most damaging group of forest pests. Entomopathogenic fungi have shown great potential for the management of some bark beetle species. The efficacy of three entomopathogenic fungi, namely, Beauveria bassiana (Balsamo) Vuillemin, Metarhizium anisopliae sensu lato (Metchnikoff) Sorokin and Lecanicillium lecanii (Zimmerman) Zare and Gams was tested against the bark beetle Pityogenes scitus Blandford under the laboratory conditions. An insecticide - cyclone 505 EC, was also used as positive control in the experiment. Each fungal suspension contained $1.0 \times 10^{9}$ spores of fungi in $1 \mathrm{ml}$. In treated branches, B. bassiana and M. anisopliae caused higher percentage of mortalities, that is, $58.33 \%$ and $48 \%$, respectively, after 10 days of treatment and $85 \%$ and $71 \%$, respectively, after 20 days of treatment. In petri plate assay, B. bassiana, $M$. anisopliae and L. lecanii caused $100 \%, 100 \%$ and $73.33 \%$ of mortality respectively. The percentage of mortality caused by treated insecticide was $79.16 \%$. The results obtained in the present study are promising; however, no recommendations concerning the potential use of these fungal pathogens in forest protection can be given, and further research studies are needed in this respect, especially under field conditions.

\section{KeY WORDS}

Pityogenes scitus, biological control, mortality, laboratory conditions

\section{INTRODUCTION}

The bark beetles (Coleoptera: Curculionidae) are amongst the most destructive wood boring insects that have induced considerable damage to the forest ecosystems globally. Majority of the species require weakened or recently felled trees for reproduction, but some species such as Pityogenes scitus (Coleoptera: Curculionidae: Scolytinae) could infest healthy trees as well, especially when climate conditions promote 
outbreak in pest population density (Yu et al. 2015). After attacking suitable host tree species, the development phase of bark beetles occurs within the bark, which includes mating, gallery construction, oviposition and brood development. Most of the vascular cambium is destroyed, and the tree is irreversibly stressed (Lieutier et al. 2009). However, the sapwood still remains functional; the canopy is alive with green foliage, and it takes weeks or months until the canopy fades and the whole tree dies (Paine et al. 1997). In addition to causing widespread tree mortality, beetle pests substantially change forest structure, composition and function. Colonised trees become hosts to dozens of arthropod, nematode and vertebrate species (Raffa et al. 2008). As biological control is becoming more acceptable as a practical science and the danger of long-term use of chemical pesticides is fully appreciated, there has been a resurgence of interest in using fungal pathogens to combat insect pests. In contrast to all other pathogen groups associated with bark beetles, entomopathogenic fungi have been well studied and evaluated as bark beetle control agents (Popa et al. 2012). There are minimal effects of entomopathogenic fungi on non-targets, and they offer a safer alternative for use in integrated pest management (IPM) than chemical insecticides (Wegensteiner 1996; Inglis et al. 2001; Batta 2007; Buhroo et al. 2016).

Entomopathogenic fungi similar to most fungal pathogens infect their host through the external cuticle. This mode of infection is the unique characteristic of the fungi. The infective units are the conidia, borne on specialised stalks called conidiophores; sporulation and germination require high humidity and adequate temperatures. Fungi gain access to the insect directly through the insect's integument. After germination of the conidium on the insect's cuticle, the fungus penetrates the integument and proliferates throughout the host, ultimately resulting in death of the infected host. Host specificity of entomopathogenic fungi varies considerably; some species have a broad host range and others are more restricted (Vincent et al. 2007; Vega et al. 2012; Mudroncekova et al. 2013). In the present study, a standardised bioassay was developed and the efficacy of three entomopathogenic fungi, namely, Beauveria bassiana (Balsamo) Vuillemin (Ascomycota: Hypocreales: Cordycipitaceae), Metarhizium anisopliae sensu lato (Metchnikoff) Sorokin (Ascomycota: Hypocre- ales: Clavicipitaceae) and Lecanicillium lecanii (Zimmerman) Zare and Gams (Ascomycota: Hypocreales: Cordycipitaceae), against $P$. scitus was investigated under laboratory conditions.

\section{Material AND MEthodS}

\section{Fungal treatment of Pinus wallichiana branches infested with $P$. scitus}

Naturally infested branches of Pinus wallichiana A.B. Jacks (Pinaceae) were collected in June 2017 from a severely infested pine stand located near forest check point, Tangmarg $\left(34^{\circ} 03.797^{\prime} \mathrm{N}, 74^{\circ} 24.948^{\prime} \mathrm{E}\right.$, Elevation $7552 \mathrm{ft}$ ) in Baramulla District, Jammu and Kashmir, India. The purpose of selection of severally infested branches with Pityogenes scitus was to ensure that the treatments would penetrate spontaneously after the application. A total of 90 branches $(27.71 \pm 1.58$ (standard deviation) $\mathrm{cm}$ in length and $3.09 \pm 0.52$ (SD) in diameter) infested with P. scitus, categorised into five groups (G1-G5), were used in the experiment. Each replicate represented three infested branches, and six replicates per experimental treatment were used (Tab. 1).

Table 1. Treatments used against naturally infested branches of Pinus wallichiana with the bark beetle, Pityogenes scitus under laboratory conditions $\left(28 \pm 3.12^{\circ} \mathrm{C}\right.$ and $77.64 \pm 7.45 \%$ $\mathrm{RH})$. Standard deviation (SD) is added in parentheses

\begin{tabular}{|c|c|c|c|c|c|c|}
\hline \multirow{2}{*}{ 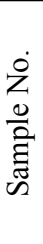 } & \multirow{2}{*}{ 节 } & \multirow{2}{*}{ 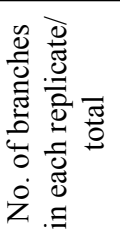 } & \multicolumn{2}{|c|}{$\begin{array}{c}\text { No. of } \\
\text { debarked } \\
\text { branches }\end{array}$} & \multirow[b]{2}{*}{ Treatments } & \multirow{2}{*}{ 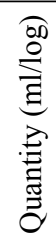 } \\
\hline & & & 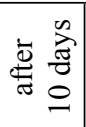 & 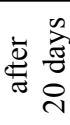 & & \\
\hline 1 & G1 & $3 / 18$ & 9 & 9 & $\begin{array}{l}\text { Beauveria } \\
\text { bassiana }\end{array}$ & 500 \\
\hline 2 & $\mathrm{G} 2$ & $3 / 18$ & 9 & 9 & $\begin{array}{l}\text { Metarhizium } \\
\text { anisopliae }\end{array}$ & 500 \\
\hline 3 & G3 & $3 / 18$ & 9 & 9 & $\begin{array}{l}\text { Lecanicillium } \\
\text { lecanii }\end{array}$ & 500 \\
\hline 4 & G4 & $3 / 18$ & 9 & 9 & Insecticide & 500 \\
\hline 5 & G5 & $3 / 18$ & 9 & 9 & $\begin{array}{l}\text { Distilled } \\
\text { water }\end{array}$ & 500 \\
\hline
\end{tabular}

* Each group represents 18 infested branches with 6 replicates per experimental treatment. Each replica contains three infested branches treated with 5 treatments 
The commercial bioprepration of entomopathogenic fungi was obtained from Green Life Biotech Laboratory, Somanur, Coimbatore, India. They included B. bassiana, M. anisopliae and L. lecanii. The insecticide used was Cyclone 505 EC (positive control) (active ingredients: Chlorpyriphos 50\% + Cypermethrin 5\%), which was applied following the standard directions for use, and distilled water sprayed on infested branches served as control during the course of experimentation.

The fungal preparation was diluted in water: $1 \mathrm{ml}$ biopreparation/1000 $\mathrm{ml}$ water with four drops of a common detergent as a wetting agent. Each fungal suspension contained $1.0 \times 10^{9}$ spores of fungi in $1 \mathrm{ml}$. The fungal suspensions were applied using a hand sprayer at $500 \mathrm{ml}$ per log (Tab. 1). High volumes of fungal suspensions were used for effective treatment so that suspensions would penetrate spontaneously after application. After 10 days, 9 branches from 3 treated replicates in each group were carefully debarked, and the percentage of mortality of $P$. scitus was calculated and compared (Tab. 1). The same procedure was applied for calculating percentage of mortality of $P$. scitus after 20 days of treatment.

\section{Fungal treatment of $P$. scitus adults (Petri plate assay)}

In this method, a total of 15 petri dishes containing filter papers were used; three replicates were maintained for each treatment. The treatments were performed by applying two rapid jetting sprays standardised at $1.0 \mathrm{ml}$ per replicate using a small calibrated hand sprayer (1 L capacity) equipped with a nozzle suited to low-volume spray application (Batta 2007). In each petri dish, 40 adults of $P$. scitus were introduced before spraying. The same spray volumes ( $1 \mathrm{ml}$ per replicate) were applied in the other treatments (Tab. 2). The mortality percentage from each treated group was evaluated after 2, 4 and 6 days of treatment. This mortality was shown either by the lack of movement of treated adults within 5-min. period of continuous observation or by the appearance of mycelial growth on the bodies of dead adults. The beetles were then incubated in petri dishes under humid conditions at $28 \pm 3.12^{\circ} \mathrm{C}$ and $77.64 \pm 7.45 \%$ relative humidity $(\mathrm{RH})$ for 1 week to promote mycelial growth with the conidia and the conidiophores on their bodies.
Table 2. Treatments used against the bark beetle Pityogenes scitus using petri plate assay under laboratory conditions $\left(28 \pm 3.12^{\circ} \mathrm{C}\right.$ and $\left.77.64 \pm 7.45 \% \mathrm{RH}\right)$. Standard deviation (SD) is added in parentheses

\begin{tabular}{|c|c|c|c|c|}
\hline 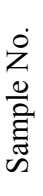 & $\stackrel{*^{*}}{\stackrel{0}{O}}$ & 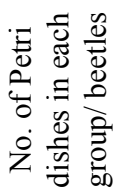 & Treatments & 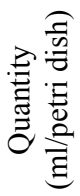 \\
\hline 1 & G1 & $3 / 120$ & Beauveria bassiana & 1.0 \\
\hline 2 & G2 & $3 / 120$ & Metarhizium anisopliae & 1.0 \\
\hline 3 & G3 & $3 / 120$ & Lecanicillium lecanii & 1.0 \\
\hline 4 & G4 & $3 / 120$ & Insecticide & 1.0 \\
\hline 5 & G5 & $3 / 120$ & Distilled water & 1.0 \\
\hline
\end{tabular}

* Each group represents 3 petri dishes with 40 adult beetles of $P$. scitus treated with 5 treatments

\section{Statistical analyses}

Statistical analyses were performed using OriginPro (Version 15) software. Data obtained on means of percentage of mortality of $P$. scitus adults in the different experimental treatments were analysed using analysis of variance (ANOVA), and means of the treatment effects were separated using Fisher's Least Significant Difference (LSD) pair-wise multiple comparison test.

\section{Results}

The results on mortality caused by entomopathogenic fungi were recorded in treated branches and petri plate assay. In treated branches, after 10 days of treatment (Tab. 3), at spore concentration of $1.0 \times 10^{9}$, percentage of mortality of $P$. scitus observed was $58.33 \%( \pm 4.27$ Standard error) with $B$. bassiana, $48 \%$ ( $\pm 4.03 \mathrm{SE})$ with M. anisopliae, $30.76 \%( \pm 3.61 \mathrm{SE})$ with $L$. lecanii and $13 \%$ ( $\pm 1.72 \mathrm{SE})$ with insecticide (positive control). Treatments with $B$. bassiana and $M$. anisopliae resulted in significantly higher mortality $(\mathrm{p}<0.05)$ than with other treatments. There were no significant differences between the mortalities caused by B. bassiana and M. anisopliae. After 20 days of treatment (Tab. 3), percentage of mortality reached a maximum of $85 \%( \pm 5.59 \mathrm{SE})$ with B. bassiana, $71 \%( \pm 6.03 \mathrm{SE})$ with $M$. anisopliae, $64.61 \%$ ( $\pm 6.61 \mathrm{SE})$ with L. lecanii and $12.22 \%( \pm 2.71 \mathrm{SE})$ with 
Table 3. Mean percentage of mortality of Pityogenes scitus individuals in experiment by comparing the efficiency of different treatments applied on infested branches of Pinus wallichiana under laboratory conditions $\left(28 \pm 3.12^{\circ} \mathrm{C}\right.$ and $77.64 \pm 7.45 \%$ $\mathrm{RH})$. Means in the column followed by different letters are significantly different at $\mathrm{p}<0.05$ as indicated by Fisher's Least Significant Difference (LSD) pair-wise multiple comparison test

\begin{tabular}{|c|l|c|c|c|c|c|c|}
\hline \multirow{2}{*}{ Groups* } & \multirow{2}{*}{ Treatment } & \multicolumn{4}{|c|}{ Mean mortality \pm Standard error (\%) } & \multicolumn{2}{c|}{$\begin{array}{c}\text { Death of P. scitus } \\
\text { individuals/total }\end{array}$} \\
\cline { 3 - 8 } & & after 10 days & difference & after 20 days & difference & after 10 days & after 20 days \\
\hline G1 & Beauveria bassiana & $58.33 \pm 4.27$ & $\mathrm{a}$ & $85 \pm 5.59$ & $\mathrm{a}$ & $70 / 120$ & $68 / 80$ \\
\hline G2 & Metarhizium anisopliae & $48 \pm 4.03$ & $\mathrm{ac}$ & $71 \pm 6.03$ & $\mathrm{a}$ & $48 / 100$ & $78 / 110$ \\
\hline G3 & Lecanicillium lecanii & $30.76 \pm 3.61$ & $\mathrm{bc}$ & $64.61 \pm 6.61$ & $\mathrm{a}$ & $40 / 130$ & $84 / 130$ \\
\hline G4 & Insecticide & $13 \pm 1.72$ & $\mathrm{~d}$ & $12.22 \pm 2.71$ & $\mathrm{~b}$ & $13 / 100$ & $11 / 90$ \\
\hline G5 & Distilled water & $6.66 \pm 2$ & $\mathrm{~d}$ & $17.5 \pm 2.88$ & $\mathrm{~b}$ & $6 / 90$ & $21 / 120$ \\
\hline
\end{tabular}

* Each group represents 18 infested branches with 6 replicates per experimental treatment. Each replica contains three infested branches treated with 5 treatments

insecticide. No significant differences were observed within fungal treatments; however, all treated fungal species caused significantly higher mortality than other treatments, that is, insecticide and distilled water. The present results indicated high ability of the fungal mycelium to grow saprophytically on the treated branches, on the bodies of infected beetles, and in the galleries of $P$. scitus adults. The results also showed higher efficacy of treatments of $B$. bassiana against $P$. scitus adults infesting $P$. wallichiana.

In petri plate assay, after 2 days of treatment (Tab. 4), at spore concentration of $1.0 \times 10^{9}$, percentage of mortality of P. scitus observed was $47.5 \%$ $( \pm 1.0 \mathrm{SE})$ with $B$. bassiana, $50.83 \%( \pm 2.08 \mathrm{SE})$ with M. anisopliae, $30.83 \%( \pm 2.0 \mathrm{SE})$ with $L$. lecanii and
$66.66 \%( \pm 3.78 \mathrm{SE})$ with insecticide. Treatment with insecticide resulted in significantly higher mortality $(p<0.05)$ than with other treatments. However, no significant differences $(\mathrm{p}<0.05)$ were observed between the percentages of mortality caused by B. bassiana and M. anisopliae. After 4 days of treatment (Tab. 4), percentage of mortality of $P$. scitus observed was $83.33 \%$ ( $\pm 1.52 \mathrm{SE})$ with B. bassiana, $89.16 \%( \pm 1.52 \mathrm{SE})$ with M. anisopliae, $44.16 \%( \pm 1.52 \mathrm{SE})$ with $L$. lecanii and $72.5 \%$ ( $\pm 4.35 \mathrm{SE})$ with insecticide. Treatments with M. anisopliae, B. bassiana and insecticide caused significantly higher mortality $(\mathrm{p}<0.05)$ than with other treatments. No significant differences $(\mathrm{p}<0.05)$ were observed between the mortalities caused by $B$. bassiana and $M$. anisopliae but both the species caused signifi-

Table 4. Mean percentage of mortality of Pityogenes scitus adults using petri plate assay under laboratory conditions $\left(28 \pm 3.12^{\circ} \mathrm{C}\right.$ and $\left.77.64 \pm 7.45 \% \mathrm{RH}\right)$. Means in the column followed by different letters are significantly different at $\mathrm{p}<0.05$ as indicated by Fisher's Least Significant Difference (LSD) pair-wise multiple comparison test

\begin{tabular}{|c|l|c|c|c|c|c|c|}
\hline \multirow{2}{*}{ Groups* } & \multirow{2}{*}{ Treatment } & \multicolumn{5}{|c|}{ Mean mortality \pm Standard error (\%) } \\
\cline { 3 - 8 } & & after 2 days & difference & after 4 days & difference & after 6 days & difference \\
\hline G1 & Beauveria bassiana & $47.50 \pm 1.0$ & $\mathrm{a}$ & $83.33 \pm 1.52$ & $\mathrm{a}$ & $100 \pm 0.00$ & $\mathrm{a}$ \\
\hline G2 & Metarhizium anisopliae & $50.83 \pm 2.08$ & $\mathrm{a}$ & $89.16 \pm 1.52$ & $\mathrm{a}$ & $100 \pm 0.00$ & $\mathrm{a}$ \\
\hline G3 & Lecanicillium lecanii & $30.83 \pm 2.08$ & $\mathrm{~b}$ & $44.16 \pm 1.52$ & $\mathrm{~b}$ & $73.33 \pm 1.52$ & $\mathrm{~b}$ \\
\hline G4 & Insecticide & $66.66 \pm 3.78$ & $\mathrm{c}$ & $72.50 \pm 4.35$ & $\mathrm{c}$ & $79.16 \pm 3.78$ & $\mathrm{~b}$ \\
\hline G5 & Distilled water & $3.33 \pm 0.57$ & $\mathrm{~d}$ & $9.16 \pm 0.57$ & $\mathrm{~d}$ & $11.66 \pm 1.15$ & $\mathrm{c}$ \\
\hline
\end{tabular}

* Each group represents 3 petri dishes with 40 adult beetles of $P$. scitus treated with 5 treatments 
cantly higher mortality $(\mathrm{p}<0.05)$ than other treatments. After 6 days of treatment (Tab. 4), percentage of mortality of $P$. scitus reached a maximum of $100 \%( \pm 0.00 \mathrm{SE})$ with B. bassiana, $100 \%$ ( $\pm 0.00 \mathrm{SE})$ with $M$. anisopliae, $73.33 \%( \pm 1.52 \mathrm{SE})$ with $L$. lecanii and $79.16 \%$ $( \pm 4.35 \mathrm{SE})$ with insecticide. Treatment with $B$. bassiana and $M$. anisopliae resulted in significantly higher mortality $(\mathrm{p}<0.05)$ than other treatments. There were no significant differences between the mortalities caused by $B$. bassiana and $M$. anisopliae. Incubation of treated $P$. scitus adults with three fungal species, namely, B. bassiana, M. anisopliae and L. lecanii in petri dishes under humid conditions at $28 \pm 3.12^{\circ} \mathrm{C}$ and $77.64 \pm 7.45 \%$ $\mathrm{RH}$ for 1 week has revealed the appearance of white mycelium on the bodies of infected beetles with conidiophores and conidia typical to the fungi as compared with the uninfected ones.

\section{Discussion}

In the present study, all fungal treatments used showed high efficacy in treated branches infested with $P$. scitus. However, B. bassiana and M. anisopliae caused higher percentages of mortality, that is, $58.33 \%$ and $48 \%$, respectively, after 10 days of treatment and $85 \%$ and $71 \%$, respectively, after 20 days of treatment. Such efficacy could be explained by the ability of the fungus mycelium to grow saprophytically in the galleries of $P$. scitus and the ability of the conidia borne by this mycelium to infect the beetles inside the galleries. Kirschner (2001) reported many species of pathogenic fungi in the galleries of bark beetles from different tree species. Several species of pathogenic fungi have been reported to infect bark beetles and are able to kill all stages of beetle pests (Wegensteiner 2007). Numerous commercial isolates of entomopathogenic fungi have been evaluated widely as confirmed by the earlier studies of Gusteleva in 1980 and 1984, who evaluated the commercial product boverin against adult Ips subelongatus (Motschulsky) and achieved $89 \%$ mortality. As in the studies of Castrillo et al. (2011) that were performed with commercial isolates; B. bassiana Naturalis and M. brunneum F52 were found to be more virulent than B. bassiana GHA, against the bark beetle, Xylosandrus germanus (Blandford). Similar studies were performed by Doberski (1981), who found that isolates of $B$. bassiana were more virulent against larvae and adults of Scolytus scolytus (Fabricius) than Isaria farinosa (Holmsk.) Fr. and M. anisopliae. Earlier studies on the virulence of B. bassiana, M. anisopliae against scolytine bark beetles are in line with the results of the present study as Markova (2000) compared the virulence of B. bassiana, M. anisopliae, I. farinosa and Cordyceps confragosa (Mains) against Ips typographus (Linnaeus) and found that the most aggressive species was $M$. anisopliae (100\% mortality in 4 days) and the least aggressive was C. confragosa (still causing $90 \%$ mortality after 5 days). In another study with I. typographus, it was highly susceptible to both B. bassiana and M. anisopliae; $90-99 \%$ mortality was achieved in inoculated individuals (Mudroncekova et al. 2013). In bioassays against Dendroctonus micans (Erichson), one isolate of $B$. bassiana was more virulent than $M$. anisopliae isolates, I. fumosorosea, Evlachovaea sp., and other isolates of $B$. bassiana, particularly against larvae (Sevim et al. 2010). Spraying B. bassiana conidial suspensions onto the bark of I. typographus infested logs caused 29\% mortality (Jakus and Blazenec 2011). It was also observed that amongst the three species of entomopathogenic fungi tested, L. lecanii was found to be less effective than the other two fungi against the $P$. scitus under laboratory conditions.

All three fungal treatments using petri plate assay showed high efficacy against the adults of the bark beetle, $P$. scitus. All treated fungal species, that is, B. bassiana, M. anisopliae and L. lecanii, caused higher percentages of mortality, after 6 days of treatment, that is, $100 \%, 100 \%$ and $73.33 \%$, respectively, than control treated with distilled water (11.66\%). Numerous bioassays have been performed with different fungal species (and isolates) against different species of bark beetles, all demonstrating the potential to achieve high mortalities in bark beetle populations in the laboratory. The most widely studied species is B. bassiana, which has been bioassayed against a number of different bark beetle species. Doane (1959) reported B. bassiana induced mortality in larvae (92\%), pupae (87\%) and adults (61\%) of Scolytus multistriatus (Marsham). B. bassiana also caused $100 \%$ mortality in Trypodendron lineatum (O1ivier) larvae within 6-8 days (Novak and Samsinsakova 1962) and was highly pathogenic to I. typographus and S. ratzeburgi (Janson) (Bałazy 1966). Higher mortality was induced by $B$. bassiana in $S$. scolytus; the $\mathrm{LD}_{50}$ was reported as $1 \times 10^{6}$ conidia $/ \mathrm{ml}$ after 5 days $\left(\right.$ at $23^{\circ} \mathrm{C}$ 
and 100\% RH) (Barson 1976). B. bassiana caused high mortality rates in bioassays against Dendroctonus micans ( $\geq 90 \%$ ) (Tanyeli 2010). Promising activity of $B$. bassiana against bark beetles was supported by earlier studies as isolate of B. bassiana from I. duplicatus (Sahlberg) sprayed on to log sections infested with I. typographus caused $60 \%$ mortality (Andrei et al. 2013) and caused $100 \%$ mortality in the same species within four days in the laboratory (Dinu et al. 2012). The activity of $B$. bassiana extended interspecifically as evaluation of $B$. bassiana against $D$. valens (LeConte) cause up to $100 \%$ mortality within 4.60 days (Zhang et al. 2011) and inoculation of I. sexdentatus (Boerner) with dry conidial powders or conidial suspensions of B. bassiana caused more than $90 \%$ mortality within a few days in young, immature adults and also old adults (Steinwender et al. 2010). In only study, with an isolate from the L. lecanii complex was found to be infective to $S$. scolytus larvae, achieving $100 \%$ mortality within 5 days at a conidial concentration of $4.5 \times 10^{6}$ conidia/ml (Bałazy 1963; Barson 1976). It was also observed that treated insecticide (cyclone) in petri plate assay also caused higher mortality (79.16\%) after 6 days of treatment as compared with control treatment under laboratory conditions. Grosman and Upton (2006) evaluated the effectiveness of dinotefuran, emamectin benzoate (Denim), fibenzoa and imidacloprid (IMA-jet) for preventing Ips spp. attacks and brood development on standing, stressed trees and bolt sections of loblolly pine (Pinus taeda L.) in East Texas. Both emamectin benzoate and fipronil significantly and successfully reduced Ips spp. colonisation and levels of mortality in stressed trees. However, on commercial forest land, insecticides are costly and difficult to apply on a large scale. They can also disrupt the effect of natural enemies, and their effectiveness in controlling beetle outbreaks has been variable.

\section{Conclusions}

For many years, the focus of application of entomopathogenic fungi for their role in reducing the insect pest problems has been increasing. The results of our experiments carried out on the bark beetle $P$. scitus are promising; however, no recommendations concerning the potential use of these fungal pathogens in forest pro- tection can be given, and further field experiments are warranted to investigate their efficacy under more practical conditions. Further research on entomopathogenic fungi could provide better understanding of pathogenhost interactions, especially pathogen transmission and spreading in field conditions.

\section{Acknowledgements}

We would like to acknowledge Science and Engineering Research Board (SERB), Government of India, New Delhi, for providing financial assistance under their project number EMR/2015/000888.

\section{Conflict of interest}

The authors declare that they have no conflict of interest.

\section{References}

Andrei, A.M., Lupastean, D., Ciornei, C., Fatu, A.C., Dinu, M.M. 2013. Laboratory Beauveria bassiana (Bals.) Vuill. bioassays on spruce bark beetle (Ips typographus L.). IOBC/WPRS Bulletin, 90, 93-96.

Bałazy, S. 1963. The fungus Cephalosporium (Acrostalagmus) lecanii Zimm., a pathogen of beetle larvae. Acta Societatis Botanicorum Poloniae, 32, 69-80.

Bałazy, S. 1966. Living organisms regulating population density of bark beetles in spruce forests, with special reference to entomopathogenic fungi. Poznańskie Towarzystwo Przyjaciół Nauk, Wydzial Nauk Rolniczych i Leśnych, 21, 3-50.

Barson, G. 1976. Laboratory studies on the fungus Verticillium lecanii, a larval pathogen of the large elm bark beetle (Scolytus scolytus). Annals of Applied Biology, 83 (2), 207-214.

Batta, Y.A. 2007. Biocontrol of almond bark beetle (Scolytus amygdali Geurin-Meneville, Coleoptera: Scolytidae) using Beauveria bassiana (Bals.) Vuill. (Deuteromycotina: Hyphomycetes). Journal of Applied Microbiology, 103 (5), 1406-1414.

Buhroo, A.A., Rasheed, F.N., Khanday, A.L. 2016. An assessment on population density of SanJose scale Quadraspidiotus perniciosus (Comstock) and its 
biological control in Kashmir (Hemiptera: Diaspididae). Munis Entomology and Zoology, 11 (2), 434-440.

Castrillo, L.A., Griggs, M.H., Ranger, C.M., Reding, M.E., Vandenberg, J.D. 2011. Virulence of commercial strains of Beauveria bassiana and Metarhizium brunneum (Ascomycota: Hypocreales) against adult Xylosandrus germanus (Coleoptera: Curculionidae) and impact on brood. Biological Control, 58 (2), 121-126.

Dinu, M.M., Lupastean, D., Cardas, G., Andrei, A.M. 2012. New Beauveria bassiana (Bals.) Vuill. isolate from Ips duplicatus (Sahlberg). Romanian Journal of Plant Protection, 5, 12-15.

Doane, C.C. 1959. Beauveria bassiana as a pathogen of Scolytus multistriatus. Annals of the Entomological Society of America, 52 (1), 109-111.

Doberski, J.W. 1981. Comparative laboratory studies on three fungal pathogens of the elm bark beetle, Scolytus scolytus: Pathogenicity of Beauveria bassiana, Metarhizium anisopliae, and Paecilomyces farinosus to larvae and adults of S. scolytus. Journal of Invertebrate Pathology, 37 (2), 188-194.

Grosman, D.M., Upton, W.W. 2006. Efficacy of systemic insecticides for protection of loblolly pine against southern pine engraver beetles (Coleoptera: Curculionidae: Scolytinae) and wood borers (Coleoptera: Cerambycidae). Journal of Economic Entomology, 99 (1), 94-101.

Gusteleva, L.A. 1980. Beauveria bassiana (Bals) Vuill preparation effect on Ips subelongatus Motsch. Leatsch results of the test. Izvestiya Sibirskogo Otdeleniya Akademii Nauk Sssr Seriya Biologicheskikh Nauk, 49-54.

Gusteleva, L.A. 1984. Virulence of Beauveria bassiana (Bals.) Vuill to the larvae of the bark beetle Ips subelongatus Motsch. (Coleoptera, Scolytidae). Revue d'Entomologie de l'URSS, 63, 40-42.

Inglis, G.D., Goettel, M.S., Butt, T.M., Strasser, H. 2001. Use of hyphomycetous fungi for managing insect pests. In: Fungi as Biocontrol Agents. Progress, Problems and Potential (eds.: T.M. Butt, C.W. Jackson, N. Magan). CABI Publishing, Wallingford, 23-69.

Jakus, R., Blazenec, M. 2011. Treatment of bark beetle attacked trees with entomopathogenic fungus Beauveria bassiana (Balsamo) Vuillemin. Folia
Forestalia Polonica, Series A - Forestry, 53 (2), $150-155$.

Kirschner, R. 2001. Diversity of filamentous fungi in bark beetle galleries in Central Europe. In: Trichomycetes and Other Fungal Groups: Professor Robert W. Lichtwardt Commemoration Volume (eds.: J.K. Misra, B.W. Horn). B.W. Science Publishers, Inc., Enfield, 175-196.

Lieutier, F., Yart, A., Salle, A. 2009. Stimulation of tree defenses by Ophiostomatoid fungi can explain attack success of bark beetles on conifers. Annals of Forest Science, 66 (8), 801.

Markova, G. 2000. Pathogenicity of several entomogenous fungi to some of the most serious forest insect pests in Europe. IOBC/WPRS Bulletin, 23, 231-239.

Mudroncekova, S., Mazan, M., Nemcovic, M., Salomon, I. 2013. Entomopathogenic fungus species Beauveria bassiana (Bals.) and Metarhizium anisopliae (Metsch.) used as mycoinsecticide effective in biological control of Ips typographus (L.). The Journal of Microbiology, Biotechnology and Food Sciences, 2 (6), 2469-2472.

Novak, V., Samsinsakova, A. 1962. Les essais d'aplication du champignon parasite Beauveria bassiana (Bals.) Vuill. dans la lutte contreles parasites en agriculture et sylviculture en CSSR. Colloques Internationaux de Pathologique des Insectes, Paris, 133-135.

Paine, T.D., Raffa, K.F., Harrington, T.C. 1997. Interactions among scolytid bark beetles, their associated fungi, and live host conifers. Annual Review of Entomology, 42 (1), 179-206.

Popa, V., Deziel, E., Lavallee, R., Bauce, E., Guertin, C. 2012. The complex symbiotic relationships of bark beetles with microorganisms: a potential practical approach for biological control in forestry. Pest Management Science, 68 (7), 963-975.

Raffa, K.F., Aukema, B.H., Bentz, B.J., Carroll, A.L., Hicke, J.A., Turner, M.G., Romme, W.H. 2008. Cross-scale drivers of natural disturbances prone to anthropogenic amplification: the dynamics of bark beetle eruptions. AIBS Bulletin, 58, 501-517.

Sevim, A., Demir, I., Tanyeli, E., Demirbag, Z. 2010. Screening of entomopathogenic fungi against the European spruce bark beetle, Dendroctonus micans (Coleoptera: Scolytidae). Biocontrol Science and Technology, 20 (1), 3-11. 


\section{sciendo}

Steinwender, B., Krenn, H., Wegensteiner, R. 2010. Different effects of the insect pathogenic fungus Beauveria bassiana (Deuteromycota) on the bark beetle Ips sexdentatus (Coleoptera: Curculionidae) and on its predator Thanasimus formicarius (Coleoptera: Cleridae). Journal of Plant Diseases and Protection, 117 (1), 33-38.

Tanyeli, E., Sevim, A., Demirbag, Z., Eroglu, M., Demir, I. 2010. Isolation and virulence of entomopathogenic fungi against the great spruce bark beetle, Dendroctonus micans (Kugelann) (Coleoptera: Scolytidae). Biocontrol Science and Technology, 20 (7), 695-701.

Vega, F.E., Meyling, N.V., Luangsaard, J.J., Blackwell, M. 2012. Fungal entomopathogens. In: Insect pathology. Second Edition (eds.: F.E. Vega, H.K. Kaya). Academic Press, San Diego, 171-220.

Vincent, C., Goettel, M.S., Lazarovits, G. 2007. Biological Control: A Global Perspective. CABI, Wallingford.
Wegensteiner, R. 1996. Laboratory evaluation of Beauveria bassiana (Bals.) Vuill. against Ips typographus (Coleoptera, Scolytidae). IOBC/WPRS Bulletin, 19, 186-189.

Wegensteiner, R. 2007. Pathogens in bark beetles. In: Bark and wood boring insects in living trees in Europe, a synthesis (eds.: F. Lieutier, K.R. Day, A. Battisti, J.C. Grégoire, H.F. Evans). Springer, Dordrecht, Netherlands, 291-313.

Yu, G., Wang, H., Feng, S., Lu, X. 2015. A new pest of the lacebark pine (Pinus bungeana) in Beijing, the bark beetle Pityogenes scitus Blandford (Coleoptera: Curculionidae: Scolytinae), and its control strategies. Acta Entomologica Sinica, 58, 99-102.

Zhang, L.W., Liu, Y.J., Yao, J., Wang, B., Huang, B., Li, Z.Z., Fan, M.Z., Sun, J.H. 2011. Evaluation of Beauveria bassiana (Hyphomycetes) isolates as potential agents for control of Dendroctonus valens. Insect Science, 18 (2), 209-216. 